\title{
Photoinduced DNA Cleavage and Photocytotoxic of Phenanthroline-Based Ligand Ruthenium Compounds
}

\author{
Xia Hu ${ }^{1,2,3}$, Ning-Yi Liu ${ }^{1,2,3}$, Yuan-Qing Deng ${ }^{1,2,3}$, Shan Wang ${ }^{1,2,3}$, Ting Liu ${ }^{1,2,3}$ and Xue-Wen Liu ${ }^{1,2,3, *(D)}$ \\ 1 Hunan Province Cooperative Innovation Center for the Construction \& Development of Dongting Lake \\ Ecological Economic Zone, College of Chemistry and Materials Engineering, Hunan University of Arts and \\ Science, Changde 415000, China; xiahu@huas.edu.cn (X.H.); liuningyi@st.huas.edu.cn (N.-Y.L.); \\ Dengyuanqing@st.huas.edu.cn (Y.-Q.D.); Wangshan@st.huas.edu.cn (S.W.); Liuting@st.huas.edu.cn (T.L.) \\ 2 Hunan Provincial Key Laboratory of Water Treatment Functional Materials, Hunan University of Arts and \\ Science, Changde 415000, China \\ 3 Hunan Province Engineering Research Center of Electroplating Wastewater Reuse Technology, Hunan \\ University of Arts and Science, Changde 415000, China \\ * Correspondence: liuxuewen050@sina.com; Tel.: +86-736-7186115
}

check for updates

Citation: Hu, X.; Liu, N.-Y.; Deng, Y.-Q.; Wang, S.; Liu, T.; Liu, X.-W.

Photoinduced DNA Cleavage and

Photocytotoxic of

Phenanthroline-Based Ligand Ruthenium Compounds. Molecules 2021, 26, 3471. https://doi.org/ $10.3390 /$ molecules 26113471

Academic Editors: Zaisheng Wu, Songbai Zhang and Limin Lu

Received: 15 April 2021

Accepted: 30 May 2021

Published: 7 June 2021

Publisher's Note: MDPI stays neutral with regard to jurisdictional claims in published maps and institutional affiliations.

Copyright: (c) 2021 by the authors. Licensee MDPI, Basel, Switzerland. This article is an open access article distributed under the terms and conditions of the Creative Commons Attribution (CC BY) license (https:// creativecommons.org/licenses/by/ $4.0 /)$.

\begin{abstract}
The photophysical and biological properties of two new phenanthroline-based ligand ruthenium complexes were investigated in detail. Their DNA interaction modes were determined to be the intercalation mode using spectra titration and viscosity measurements. Under irradiation, obvious photo-reduced DNA cleavages were observed in the two complexes via singlet oxygen generation. Furthermore, complex 2 showed higher DNA affinity, photocleavage activity, and singlet oxygen quantum yields than complex 1 . The two complexes showed no toxicity towards tumor cells (HeLa, A549, and A375) in the dark. However, obvious photocytotoxicities were observed in the two complexes. Complex 2 exhibited large PIs (phototherapeutic indices) (ca. 400) towards HeLa cells. The study suggests that these complexes may act as DNA intercalators, DNA photocleavers, and photocytotoxic agents.
\end{abstract}

Keywords: ruthenium complex; photoinduced cleavage; DNA interaction; photocytotoxic

\section{Introduction}

The DNA-binding behaviors of small molecules have provoked intense interest because DNA has usually been regarded as the most important drug target for anti-tumor activity [1-8]. Many studies have shown that most of the perturbations in cellular processes may come from the different DNA-binding modes of small molecules [8-12]. In general, non-covalent and covalent binding modes have been found in the interactions between small molecules and DNA. For example, well-known platinum-based complexes show their anti-tumor activity by covalent binding to DNA [8-12], which can affect the topological structure of DNA. Meanwhile, many DNA binders have also been found to display good biological activities through non-covalent interactions, especially DNA intercalation. Recently, many intercalators have been reported to display anti-tumor activities because the DNA interactions of intercalators can induce conformational changes in DNA or normal DNA-protein interactions [13-24]. Ruthenium complexes have been frequently considered for their possible application as important biological agents due to their strong DNA binding abilities, rich photoactivity and easily constructed coordination geometry [15-24]. Most of these applications are regarded to originate from the high DNA affinity of ruthenium-based compounds. For example, $\left[\mathrm{Ru}(\mathrm{bpy})^{2}(\mathrm{dppz})\right]^{2+}$ displays a "light switch" effect during its intercalation into DNA [25]. Furthermore, many studies have revealed that changes in the structure of ligands can lead to interesting differences in DNA affinity, reactive oxygen species (ROS) quantum yields, and the DNA photocleavage abilities of ruthenium-based compounds, such as their substituent effect, and the shape and 
planarity of ligands (main ligands and ancillary ligands). Therefore, a further study is necessary to obtain new intercalative ligands and search for new ruthenium-based compounds with excellent bioactivities.

On the other hand, photodynamic therapy (PDT) agents under irradiation have shown photocytotoxic activities towards cancer cells via ROS mechanisms. The first PDT drug containing a porphyrin unit, photofrin ${ }^{\circledR}$, has been approved by the Federal Drug Administration (FDA) for the treatment of solid tumors. Recently, ruthenium complexes have been found to activate molecular oxygen into singlet oxygen $\left({ }^{1} \mathrm{O}_{2}\right)$ and to display favorable singlet oxygen quantum yields. This indicates that ruthenium-based compounds have the potential to act as PDT agents. Previous studies show that several kinds of rutheniumbased compounds have been used to confirm their photocytotoxic activities towards tumor cells, including $\mathrm{Ru}(\mathrm{II})$ polypyridyl complexes, ruthenium(II)-porphyrin conjugates, and cyclometalated ruthenium(II) complexes [26-39]. These ruthenium complexes show significant phototherapeutic indices due to their high singlet oxygen quantum yields as the result of efficient singlet oxygen photosensitization. Therefore, a further study is necessary to obtain new ruthenium-based compounds with significant singlet oxygen quantum yields and search for new phototherapeutic agents.

This work stems from our interest in obtaining new ruthenium complexes and investigating their potential biological activities. A phen (phen =1,10-phenanthroline) unit is usually introduced into organic molecules as a fluorophore to enhance their emission intensities. Furthermore, many ruthenium complexes containing a phen unit display excellent photophysical properties. Furthermore, an aromatic unit (naphthyl) was also introduced to form a naphthoimidazole unit due to its potential photophysical abilities as a fluorophore. In addition, the large aromatic plane of the naphthoimidazole unit is favorable to the DNA binding abilities of ruthenium complexes. We expected good photophysical properties, high ${ }^{1} \mathrm{O}_{2}$ quantum yield and excellent bioactivities, all of which can be improved by the modification of the main ligand. Herein, we synthesized two ruthenium complexes containing a new phen-based ligand: 2-(5-(1,10-phenanthroline))-1H-naphtha[2,3]imidazole (pni), $\left[\mathrm{Ru}(\mathrm{bpy})_{2}(\mathrm{pni})\right]\left(\mathrm{PF}_{6}\right)_{2}$, and $\left[\mathrm{Ru}(\mathrm{phen})_{2}(\mathrm{pni})\right]\left(\mathrm{PF}_{6}\right)_{2}$ (bpy = 2,2'-bipyridine). The DNA interaction, DNA photocleavage abilities, cytotoxicities in the dark, and photocytotoxicities of the two complexes were further studied.

\section{Results and Discussion}

\subsection{Synthesis and Characterization}

The condensation reaction of diamine and aldehyde in the presence of $\mathrm{NaHSO}_{3}$ in dimethylacetamide enables the creation of the ligand pni through the formation of an imidazole ring. Precursor Ru complexes and pni were combined in ethylene glycol and refluxed for $8 \mathrm{~h}$ to create the desired ruthenium complex (Scheme 1). Structural characterizations were carried out using ESI-MS spectra, NMR spectra, and elemental analysis (Figures S1 and S2). Using the MS spectra, the structures of the two complexes were identified by the presence of two peaks, $\left[\mathrm{M}-\mathrm{PF}_{6}\right]^{+}$and $\left[\mathrm{M}-2 \mathrm{PF}_{6}\right]^{2+} .{ }^{1} \mathrm{H}-\mathrm{NMR}$ spectra showed the proton signals at 13.47 and 13.48 for $\mathbf{1}$ and $\mathbf{2}$, respectively. These peaks can be attributed to the imidazole proton, which confirms the formation of imidazole ring. 

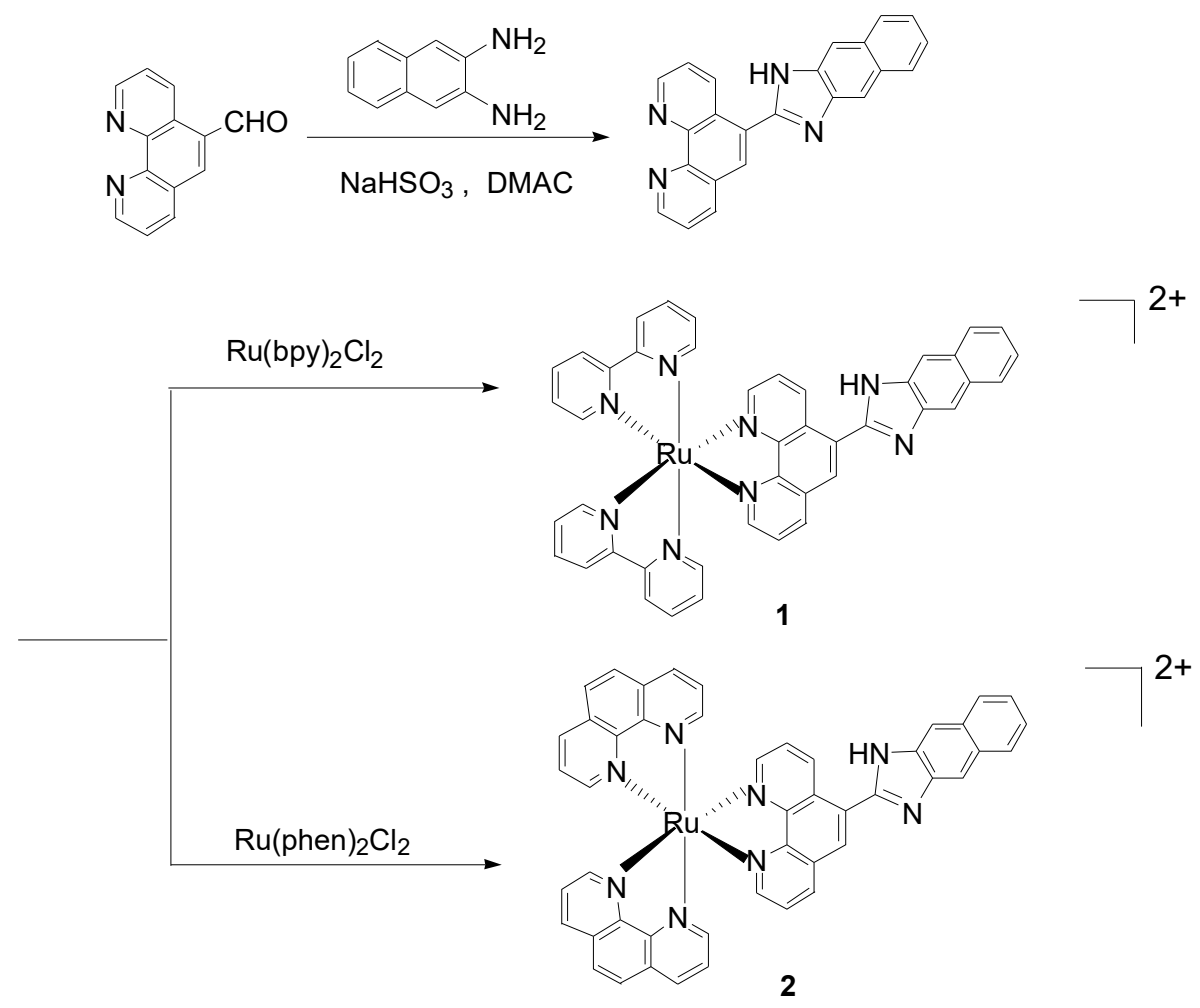

Scheme 1. Synthesis of pni, complexes 1 and 2.

\subsection{UV-Vis Spectra}

UV-visible spectra are used to determine the DNA affinities of ruthenium-based compounds. In general, when the complexes display a high DNA affinity, large decreases in absorbance will occur. Meanwhile, little change will be observed for complexes with a low DNA affinity.

Figure 1 depicts the UV-Vis spectra of two Ru complexes incubating calf thymus DNA (ct-DNA) $([\mathrm{Ru}]=20 \mu \mathrm{M})$ in a tris buffer $(5 \mathrm{mM}$ tris, $50 \mathrm{mM} \mathrm{NaCl}, \mathrm{pH}=7.2)$. The MLCT (metal-ligand charge transfer) bands of complexes 1 and 2 were found to be $452 \mathrm{~nm}$ and $445 \mathrm{~nm}$, respectively. With an increase in the amount of DNA, the absorption intensities of 1 and 2 dropped by about $11.5 \%$ and $13.6 \%$, respectively. The DNA affinities of the two complexes were evaluated using the DNA binding constant $\mathrm{K}_{\mathrm{b}}$, which can be calculated from the decrease in the absorbance at the MLCT absorption bands using Equations (1) and (2) [40]. The values of $\mathrm{K}_{\mathrm{b}}$ are $2.84 \pm 0.10 \times 10^{5} \mathrm{M}^{-1}(\mathrm{~s}=2.01)$ and $4.35 \pm 0.14 \times 10^{5} \mathrm{M}^{-1}$ $(\mathrm{s}=3.39)$ for $\mathbf{1}$ and 2 , respectively. [Ru(bpy $\left.)_{2}(\mathrm{dppz})\right]^{2+}$ has been reported to be a strong DNA binder through its intercalation with $\mathrm{K}_{\mathrm{b}}$ of $4.9 \times 10^{6} \mathrm{M}^{-1}$ [41,42]. Comparing the $\mathrm{K}_{\mathrm{b}}$ of our complexes to those of classical intercalators, our complexes displayed lower DNA affinities. The difference in DNA affinities between our complexes and those classical intercalators may be caused by the plane area of intercalative ligand. Furthermore, 2 presented a higher DNA affinity than $\mathbf{1}$. This is likely to be due to the effect of the ancillary ligand. As previous reports have shown, ancillary ligands possess a large aromatic planarity area and high hydrophobicity, usually leading to the high DNA affinity of Ru complexes [43]. 

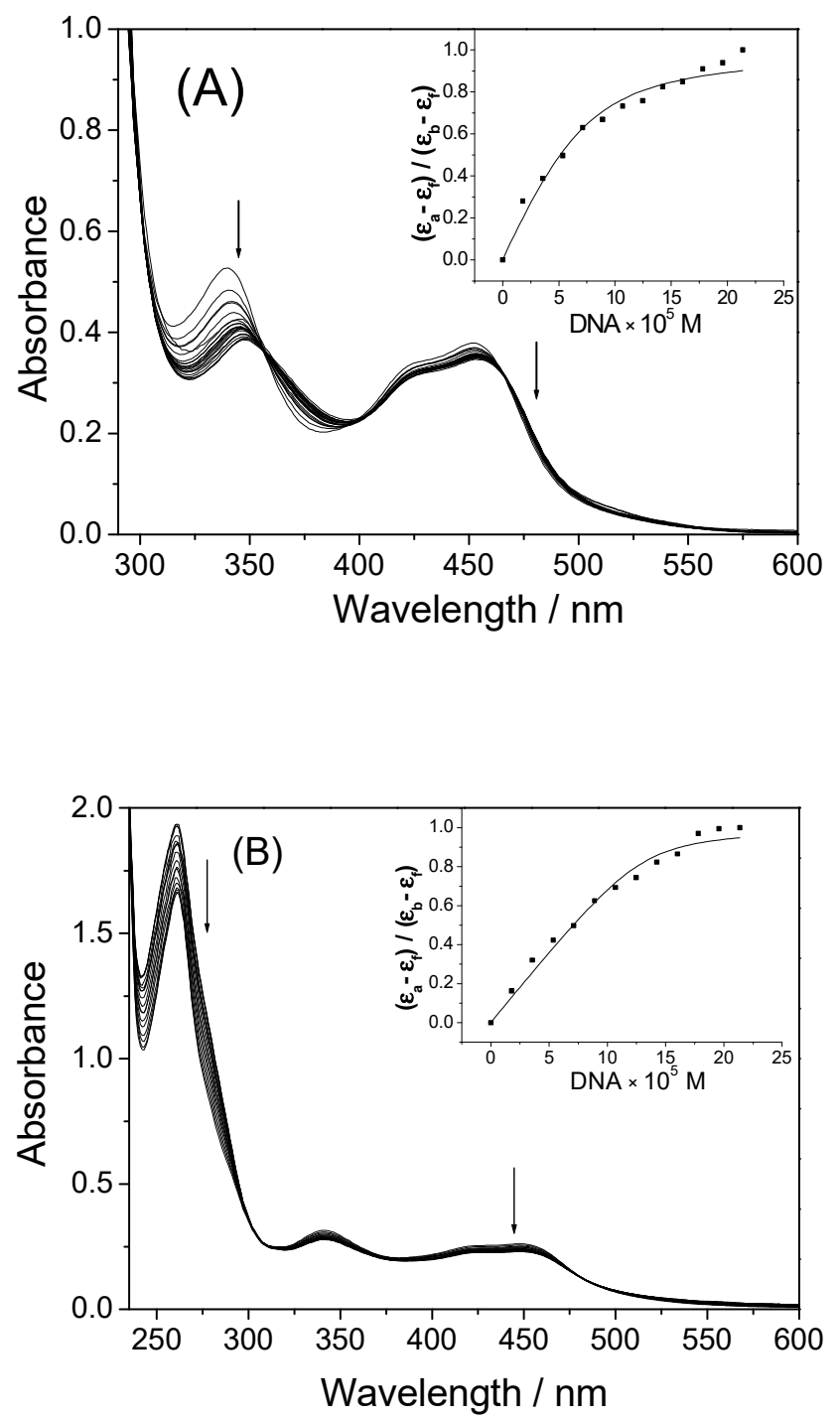

Figure 1. Absorption spectra of $\mathbf{1}(\mathbf{A})$ and $\mathbf{2}(\mathbf{B})(20 \mu \mathrm{M})$ incubating various concentrations of ct-DNA. Inset: plots of $\left(\varepsilon_{\mathrm{a}}-\varepsilon_{\mathrm{f}}\right) /\left(\varepsilon_{\mathrm{b}}-\varepsilon_{\mathrm{f}}\right)$ vs. DNA.

\subsection{Viscosity Measurements}

Another useful method to determine DNA binding modes is a viscosity experiment, which is usually used to measure changes in the length of DNA when small molecules interact with DNA. When a probe interacts with DNA, different modes can affect DNA viscosity to different degrees. For example, ethidium bromide (EB) can cause DNA viscosity to increase because it can bind with DNA by intercalation, which causes an increase in DNA length. Conversely, $\left[\mathrm{Ru}(\mathrm{bpy})_{3}\right]^{2+}$ has little effect on DNA viscosity due to its electrostatic binding mode with DNA [44-46]. Therefore, changes in DNA viscosity can enable the determination of DNA binding modes. The changes in DNA viscosities for EB, $\left[\mathrm{Ru}(\mathrm{bpy})_{3}\right]^{2+}, \mathbf{1}$ and $\mathbf{2}$ are shown in Figure 2. From Figure 2, we can see that the two complexes had a similar impact on DNA viscosity to that of EB, indicating that complex 1 and $\mathbf{2}$ interact with DNA by intercalation. Lower DNA affinities were observed for $\mathbf{1}$ and $\mathbf{2}$ compared to EB because the DNA binding mode and DNA affinity are important factors that lead to the change in the DNA viscosity. Additionally, complex 2 presents stronger DNA interaction than complex $\mathbf{1}$ based on the viscosity experiment results. 


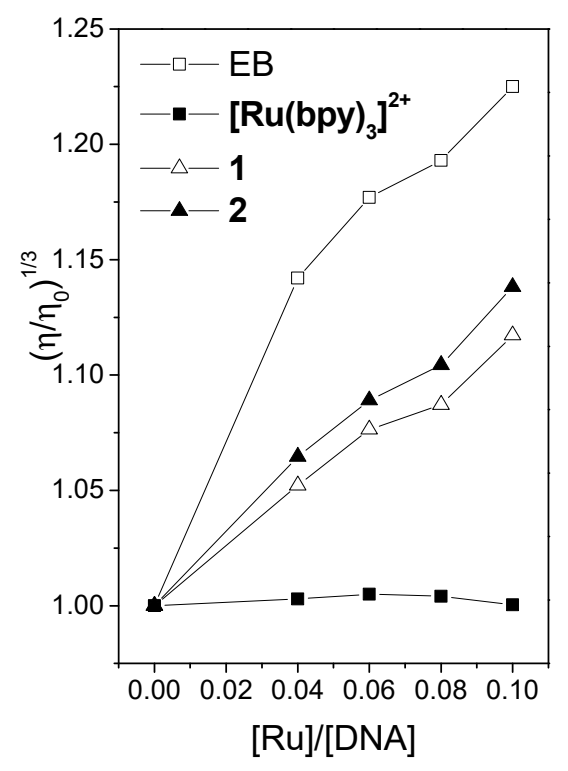

Figure 2. Comparison of DNA $(0.25 \mathrm{mM})$ viscosity of the compounds. [Ru]/[DNA] $=0,0.04,0.06$, $0.08,0.1$.

\subsection{Emission Titration Experiments}

The good photophysical properties of ruthenium-based complexes can be utilized to study their DNA interaction, because the addition of DNA can cause the perturbation of the emission properties of ruthenium complexes. The luminescence behaviors of the complexes were tested by adding ct-DNA to the solutions of the complexes, which is helpful to further understand the DNA affinity of these compounds. The results can be seen in Figure 3. When excited at $450 \mathrm{~nm}, 1$ and 2 emitted red luminescence at $606 \mathrm{~nm}$ and $600 \mathrm{~nm}$, respectively. After the complexes interacted with DNA, a large increase in emissions was observed, and the increasing ratio of emission intensity was ca. 2.34- and 1.75-times for complex $\mathbf{1}$ and $\mathbf{2}$, respectively. Here, DNA caused the large perturbation of the emission intensity of the two complexes, which demonstrated that the two complexes exhibited a high DNA affinity.
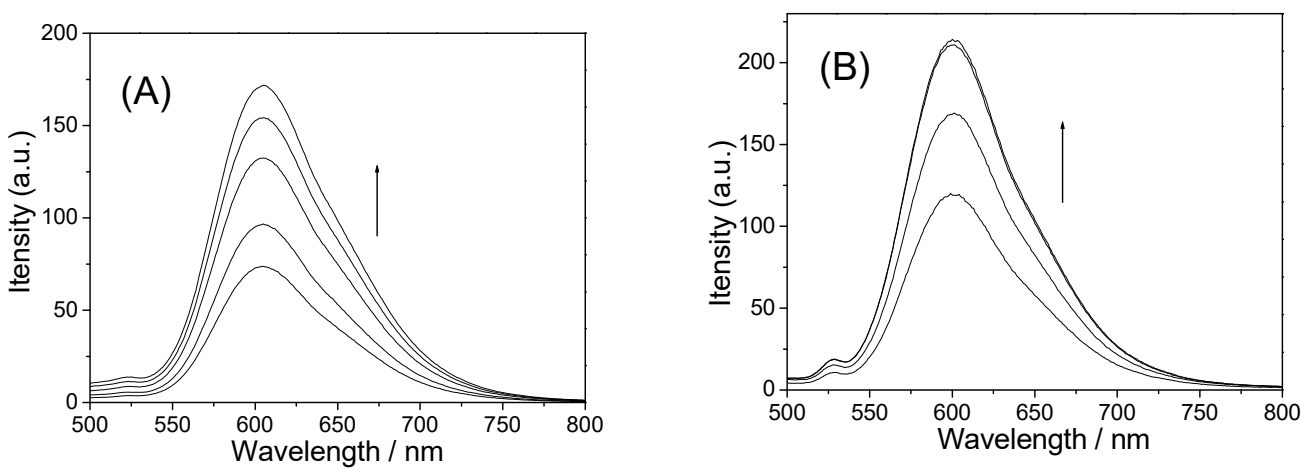

Figure 3. Luminescence spectra of complex 1 (A) and 2 (B) $(5 \mu \mathrm{M})$ with various concentrations of ct-DNA in a tris buffer.

$\left[\mathrm{Fe}(\mathrm{CN})_{6}\right]^{4-}$ can repulse DNA since both of them are polyanionic species. As previously reported, ferrocyanide can quench the luminescence of the complexes. When DNA interacts with the complexes, the emission quenching will occur due to the electrostatic attraction and coulombic repulsion between ferrocyanide and DNA. The results are shown in Figure 4. Here, similar emission-quenching behaviors were observed for our complexes. Furthermore, a higher quenching efficiency was observed in complex 1 due to its lower DNA-binding ability, as compared to complex 2. However, Turro has reported that weak 
luminescence quenching cannot prove the presence of intercalation, because weak luminescence quenching has also been observed for some complexes bound through electrostatic interaction [47]. Therefore, luminescence quenching by ferrocyanide can only reflect the degree of the DNA affinity of a complex; the binding mode cannot be determined using luminescence quenching data. These results also demonstrate that complex 2 exhibited stronger DNA interaction than $\mathbf{1}$.

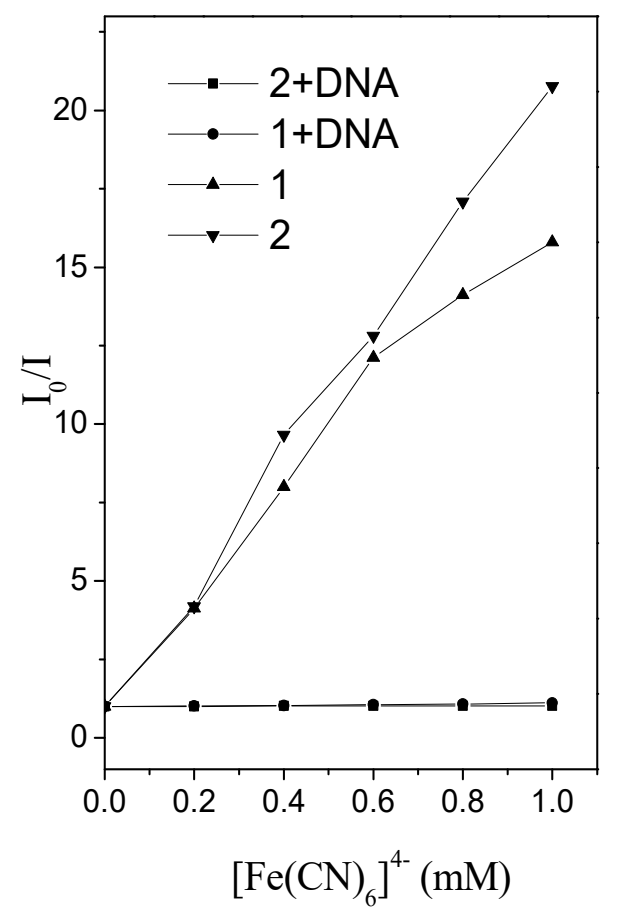

Figure 4. Luminescence quenching curves of two complexes $(5 \mu \mathrm{M})$ without or with DNA $(400 \mu \mathrm{M})$ at various concentrations of $\left[\mathrm{Fe}(\mathrm{CN})_{6}\right]^{4-}$.

\subsection{DNA Photocleavage Studies}

Ruthenium-based compounds are well known for their good photophysical properties and can serve as photoinduced metallonucleases. The main reason for this is that such compounds can activate molecular oxygen under irradiation, form reactive oxygen species, and cleave DNA [34,48]. The photo-reduced nuclease activities of the two complexes in this experiment were tested using agarose gel electrophoresis. Figure 5 depicts the photo-reduced DNA cleavage results for complex $\mathbf{1}$ and $\mathbf{2}$. The amount of Form I (the intact supercoil form) decreased and the amount of Form II (the nicked circular form) increased. Many polypyridyl ruthenium complexes have been reported to be DNA photocleavers $[30,43,49,50]$. For example, $\left[\mathrm{Ru}(\mathrm{bpy})_{2} \mathrm{dppn}\right]^{2+}(\mathrm{dppn}=4,5,9,16-$ tetraaza-dibenzo[a,c]naphthacene) can completely cleave Form I into Form II at $5 \mu \mathrm{M}$ [49]. Meanwhile, $\left[\mathrm{Ru}(\mathrm{dmb})_{2}(\mathrm{NMIP})\right]^{2+}$ cleaves most of Form I at $60 \mu \mathrm{M}[50]$ (NMIP $=2^{\prime}-$ - $^{\prime \prime}$-nitro$3^{\prime \prime}, 4^{\prime \prime}$-methylenedioxyphenyl)imidazo- $\left[4^{\prime}, 5^{\prime}-f\right][1,10]$-phenanthroline, dmb $=4,4^{\prime}$-dimethyl$2,2^{\prime}$-bipyridine). Although our complexes displayed lower photocleavage abilities than that of $\left[R u(b p y)_{2} d p p n\right]^{2+}$, obvious DNA-cleaving activities were observed for the two complexes, which demonstrated that the complexes were potentially light-activated compounds. Furthermore, $\mathbf{2}$ displayed a stronger cleaving ability compared to 1 . 

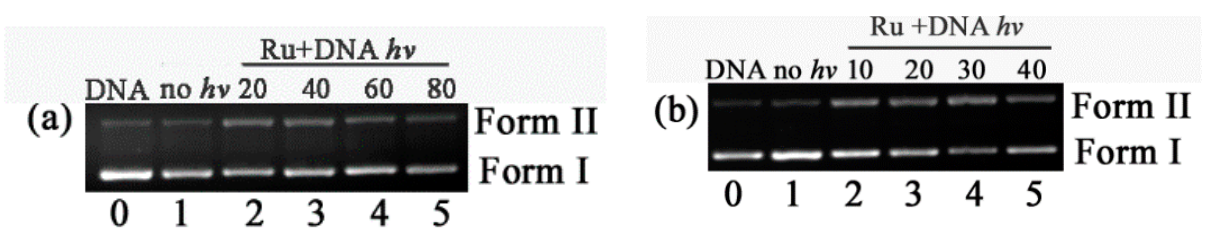

Figure 5. Photoinduced cleavage of pBR322 DNA $(0.1 \mu \mathrm{g})$ by complex $\mathbf{1}$ (a) and $\mathbf{2}(\mathbf{b})(20 \mu \mathrm{M})$ after $2 \mathrm{~h}$ irradiation. Lane 0: DNA only, no hv; lane 1: DNA + Ru(20 $\mu \mathrm{M})$, no hv; lane 2-5: DNA + Ru, hv.

The possible mechanism of photo-reduced cleavage was investigated by determining the presence of reactive oxygen species. Different scavengers were added into the photocleavage system under irradiation, such as mannitol, histidine, DMSO (DMSO = dimethyl sulfoxide), sodium azide, and SOD ( $\mathrm{SOD}=$ superoxide dismutase) $[34,43,48]$. These ROS scavengers can quench different reactive oxygen species and affect the DNA-cleaving ability of a complex. As seen in Figure 6, the obvious inhibition of DNA cleavages was observed after the addition of $\mathrm{NaN}_{3}$ and histidine to the two complexes. The results showed that ${ }^{1} \mathrm{O}_{2}$ (singlet oxygen) appeared in the DNA cleavage system, indicating that the two complexes can produce singlet oxygen under irradiation. However, no obvious inhibition of photocleavage activity was caused by SOD, DMSO or mannitol, indicating that $\mathrm{OH} \bullet$ and $\mathrm{O}_{2} \bullet^{-}$were not formed by the two complexes under irradiation. This suggested that DNA photo-reduced cleavage should be initiated by ${ }^{1} \mathrm{O}_{2}$ for complexes $\mathbf{1}$ and $\mathbf{2}$.
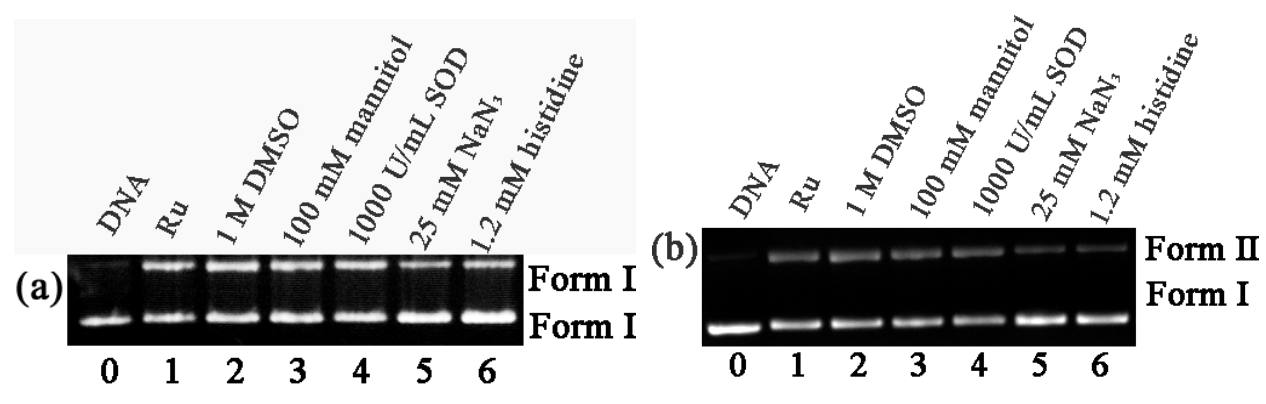

Figure 6. Photoinduced cleavage of pBR322 DNA incubating different scavengers after $2 \mathrm{~h}$ irradiation for $\mathbf{1}$ (a) and $\mathbf{2}$ (b) $(30 \mu \mathrm{M})$.

To further confirm the presence of ${ }^{1} \mathrm{O}_{2}$ in the DNA photocleavage, DPBF was used to measure the quantum yields of ${ }^{1} \mathrm{O}_{2}$. DPBF is a typical inhibitor of singlet oxygen and can emit strong fluorescence at $479 \mathrm{~nm}$. When it reacts with singlet oxygen, the amount of DPBF will decrease, leading to fluorescence quenching. Under irradiation at $450 \mathrm{~nm}$, the fluorescence quenching of DPBF by the two complexes was observed, further confirming the presence of singlet oxygen (Figure 7). Compared to $\left[\mathrm{Ru}(\mathrm{bpy})_{3}\right]^{2+}\left(\Phi_{\Delta}^{\mathrm{S}}=0.81\right.$ [51]), the $\Phi_{\Delta}$ values of complexes 1 and 2 were 0.79 and 0.82 according to Equation (S1) and (S2), respectively. The results indicated that they can produce ${ }^{1} \mathrm{O}_{2}$. Combined with the photocleavage results, ${ }^{1} \mathrm{O}_{2}$ is further confirmed to be the main reactive species during the DNA photocleavage process. 

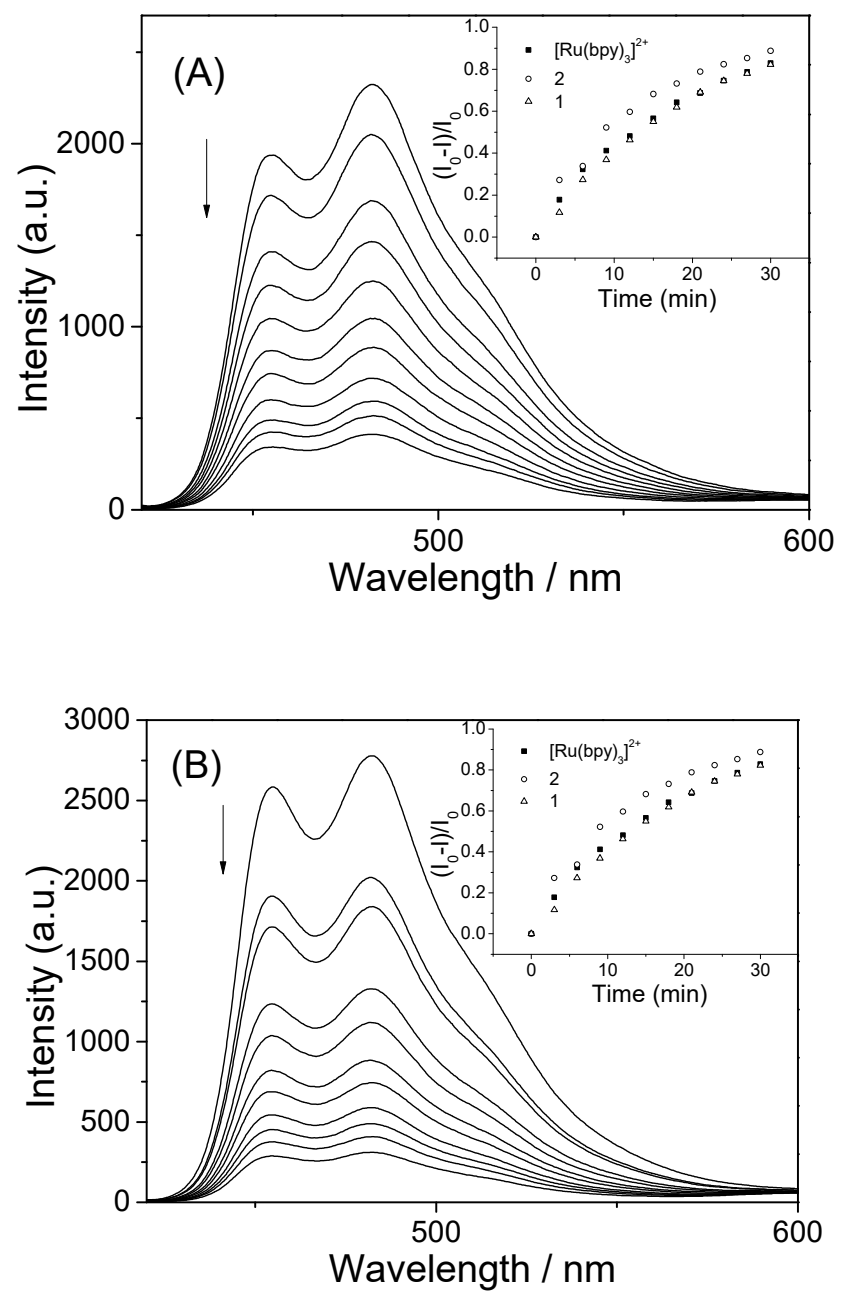

Figure 7. Fluorescence spectra of the DPBF $(20 \mu \mathrm{M})$ mixed with $\mathbf{1}(\mathbf{A})$ or $\mathbf{2}(\mathbf{B})(20 \mu \mathrm{M})$ in methanol.

\subsection{Photocytotoxicity}

The MTT method was used to assess the photocytotoxicities and dark cytotoxicities in vitro for the two complexes against HeLa, A549, and A375 cells. The IC50 values of complex 1, complex 2, and cisplatin are given in Table 1. Cisplatin showed obvious dark cytotoxicities against all cancer cells and no significant photocytotoxicities were observed. After 10 min irradiation, the two ruthenium complexes displayed significant photocytotoxicities towards all cancer cells. The photocytotoxicity index (PI) value of complex 1 against HeLa, A549, and A375 cells was 208, 227, and 244, respectively. For complex 2, the PI value was 400, 357, and 384, respectively. The cell viabilities of A549 cells in the presence of complexes $\mathbf{1}$ and $\mathbf{2}$ are shown in Figure 8. The two complexes exhibited significant inhibitory effects on cell viability (for HeLa and A375 cells (Figures S3 and S4), see supporting information). However, the two complexes did not cause obvious cytotoxicities in the dark against all cancer cells $(>100 \mu \mathrm{M})$. The results showed that the two complexes displayed low dark cytotoxicity and high phototoxicity, indicating that the two complexes can act as a potential PDT candidate. Complex 2 displayed higher photocytotoxicity than complex $\mathbf{1}$, since complex $\mathbf{2}$ displayed higher singlet oxygen quantum yields compared to complex 1. Ruthenium complexes containing phen as a co-ligand usually exhibit higher singlet oxygen quantum yields than complexes with the co-ligand bpy, due to the difference in the rigidity of the ancillary ligand. Previous studies have shown that their parent complex- $\left[\mathrm{Ru}(\mathrm{bpy})_{3}\right]^{2+}[32]$ —exhibited low cytotoxicity toward HeLa and A549 cells under light irradiation, although it displays a high ${ }^{1} \mathrm{O}_{2}$ quantum yield, indicating that ${ }^{1} \mathrm{O}_{2}$ quantum yield is not the only factor affecting photocytotoxocity. However, its 
derivative complex, $\left[\mathrm{Ru}(\mathrm{bpy})_{2} \mathrm{dppn}\right]^{2+}[52]$, displayed high photocytotoxocity after the modification of the main ligand. Therefore, these factors affected photocytotoxocity.

Table 1. (Photo)cytotoxicity against selected cell lines.

\begin{tabular}{|c|c|c|c|c|c|c|c|c|c|}
\hline \multirow{3}{*}{ Complex } & \multicolumn{9}{|c|}{$\mathrm{IC}_{50}(\mu \mathrm{M})$} \\
\hline & \multicolumn{3}{|c|}{ HeLa } & \multicolumn{3}{|c|}{ A549 } & \multicolumn{3}{|c|}{ A375 } \\
\hline & Dark & Light & PI & Dark & Light & PI & Dark & Light & PI \\
\hline 1 & $>100$ & $0.48 \pm 0.13$ & 208 & $>100$ & $0.44 \pm 0.17$ & 227 & $>100$ & $0.41 \pm 0.13$ & 244 \\
\hline 2 & $>100$ & $0.25 \pm 0.02$ & 400 & $>100$ & $0.28 \pm 0.05$ & 357 & $>100$ & $0.26 \pm 0.03$ & 385 \\
\hline$\left[\mathrm{Ru}(\mathrm{bpy})_{3}\right]^{2+}[32]$ & $>300$ & $161 \pm 5.62$ & 1.86 & $>300$ & $152 \pm 4.34$ & 1.97 & & & \\
\hline $\begin{array}{c}{\left[\mathrm{Ru}(\mathrm{bpy})_{2} \mathrm{dppn}\right]^{2+}} \\
{[52]}\end{array}$ & $110 \pm 28$ & $0.39 \pm 0.06$ & 282 & & & & & & \\
\hline Cisplatin & $45.75 \pm 3.31$ & $43.61 \pm 5.52$ & 1.05 & $38.27 \pm 2.46$ & $33.81 \pm 5.17$ & 1.13 & $33.86 \pm 3.82$ & $30.63 \pm 5.47$ & 1.11 \\
\hline
\end{tabular}

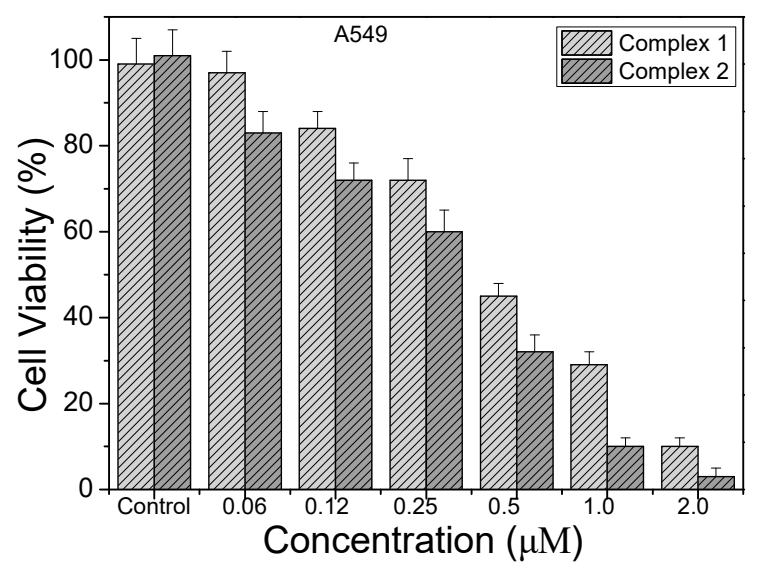

Figure 8. Cell viabilities of A549 cells pretreated with various concentrations of complexes $\mathbf{1}$ and 2 for $12 \mathrm{~h}$ and irradiated at $450 \mathrm{~nm}$, for $10 \mathrm{~min}\left(6 \mathrm{~mW} / \mathrm{cm}^{2}\right)$.

\section{Materials and Methods}

\subsection{Instrumentation}

ESI mass spectra were obtained using an LCQ system (Finnigan MAT, San Jose, CA, USA). Microanalysis was performed using a Perkin-Elmer $240 \mathrm{Q}$ elemental analyzer. ${ }^{1} \mathrm{H}$ NMR and ${ }^{13} \mathrm{C}$-NMR spectra were collected in $\left(\mathrm{CD}_{3}\right)_{2} \mathrm{SO}$ using a Bruker 2000 spectrometer.

\subsection{DNA Interactions}

The DNA interactions of the complexes were assessed using UV titration at room temperature. The concentration of the ct-DNA solution was determined by absorption spectroscopy $[49,50,53]$. After the addition of ct-DNA into the solutions of the ruthenium complexes $(20 \mu \mathrm{M})$, UV-Vis spectra were recorded every $5 \mathrm{~min}$. McGhee's equations (Equations (1) and (2)) were used to determine the values of $K$ for the ruthenium-based compounds 1 and 2 [40].

$$
\begin{gathered}
\left(\varepsilon_{a}-\varepsilon_{f}\right) /\left(\varepsilon_{b}-\varepsilon_{f}\right)=\left(b-\left(b^{2}-2 K^{2} C_{t}[\mathrm{DNA}] / s\right)^{1 / 2}\right) / 2 K C_{t} \\
b=1+K C_{t}+K[\mathrm{DNA}] / 2 s
\end{gathered}
$$

where $\varepsilon_{a}, \varepsilon_{f}$, and $\varepsilon_{b}$ corresponds to the molar absorptivity of the DNA-bound complex, the free complex, and the DNA-saturated complex, respectively. $s$ is the binding site size. Here, the value of $C_{t}$ is $20 \mu \mathrm{M}$ for the ruthenium complexes. $K$ is the binding constant of the ruthenium complexes. 
Emission titration experiments were performed by adding various concentrations of ctDNA into the solutions of the ruthenium complexes $(5 \mu \mathrm{M})$ at room temperature. Emission quenching experiments were also carried out, using $\left[\mathrm{Fe}(\mathrm{CN})_{6}\right]^{4-}$ as the quencher. In general, various concentrations $\left[\mathrm{Fe}(\mathrm{CN})_{6}\right]^{4-}$ were added to the solutions of the ruthenium complexes $(5 \mu \mathrm{M})$ or Ru-DNA $([\mathrm{Ru}]=5 \mu \mathrm{M}$; [DNA $]=400 \mu \mathrm{M})$. The luminescence spectra were recorded in the range of 500 to $800 \mathrm{~nm}$ with an excitation wavelength of $450 \mathrm{~nm}$.

\subsection{Photoinduced DNA Cleavage}

The photoinduced cleavage experiments were carried out under irradiation at $365 \mathrm{~nm}$. Various concentrations of the Ru compounds were added to solutions of pBR322 DNA $(0.1 \mu \mathrm{g})$. Then, the mixture was irradiated at $365 \mathrm{~nm}$. Gel electrophoresis was used to evaluate the DNA cleaving abilities of the complexes under irradiation.

\subsection{Singlet Oxygen Quantum Yield Measurement}

The quantum yields $(\Phi \Delta)$ of ${ }^{1} \mathrm{O}_{2}$ were tested using an ${ }^{1} \mathrm{O}_{2}$ quencher and DPBF $(1,3-$ diphenylisobenzofuran) in $\mathrm{CH}_{3} \mathrm{OH}$. The methanol solutions of DPBF and the complexes were irradiated at $450 \mathrm{~nm}$. The fluorescence spectra of the DPBF were collected every $3 \mathrm{~min}$ $\left(\lambda_{\mathrm{ex}}=405 \mathrm{~nm}, \lambda_{\mathrm{em}}=479 \mathrm{~nm}\right)$. Quantum yields $(\Phi \Delta)$ of ${ }^{1} \mathrm{O}_{2}$ were obtained according to the reported equation [53] (supporting information).

\subsection{Photocytotoxicity}

Hela, A549, and A375 cells (5000 cells) were cultured separately in 96-well plates overnight. Various concentrations of the $\mathrm{Ru}$ compounds or cisplatin were added to the cells and kept in the dark for $12 \mathrm{~h}$. A fresh medium was used for subsequent experiments. The cells were irradiated for $10 \mathrm{~min}$ (LED system $450 \mathrm{~nm}, 6 \mathrm{~mW} / \mathrm{cm}^{2}$ ) and kept in the dark for another $36 \mathrm{~h}$. The standard MTT method was used to obtain the IC50 values of the complexes.

\subsection{Synthesis}

2,3-diaminonaphthalene, was obtained commercially. 1,10-phenanthroline-5-carbaldehyde, and the precursor ruthenium complexes, $\left[\mathrm{Ru}(\mathrm{L})_{2} \mathrm{Cl}_{2}\right] \cdot 2 \mathrm{H}_{2} \mathrm{O}(\mathrm{L}=$ bpy and phen), were prepared according to the reported method [54-56].

\subsubsection{2-(5-(1,10-Phenanthroline))-1H-naphtha[2,3]imidazole (pni)}

$\mathrm{NaHSO}_{3}(0.208 \mathrm{~g}, 2.0 \mathrm{mmol})$, 2,3-diaminonaphthalene $(0.158 \mathrm{~g}, 1.0 \mathrm{mmol})$, and 1 , 10-phenanthroline-5-carbaldehyde $(0.208 \mathrm{~g}, 1.0 \mathrm{mmol})$ were added to $10 \mathrm{~mL}$ dimethylacetamide. The solution was refluxed for $6 \mathrm{~h}$. Then, $150 \mathrm{~mL}$ of water was added, yielding a dark brown precipitate. Yield: $81.1 \%$. Anal (\%): ESIMS: $m / z=347([\mathrm{M}+1]+) .{ }^{1} \mathrm{H}-\mathrm{NMR}$ $\left(400 \mathrm{MHz}, \mathrm{ppm}, \mathrm{DMSO}-\mathrm{d}^{6}\right): 9.83(\mathrm{~d}, 1 \mathrm{H}, J=8.0 \mathrm{~Hz}), 9.21(\mathrm{~d}, 2 \mathrm{H}, J=4.0 \mathrm{~Hz}), 8.71(\mathrm{~s}, 1 \mathrm{H})$, $8.63(\mathrm{~d}, 1 \mathrm{H}, J=8.0 \mathrm{~Hz}), 8.26(\mathrm{~s}, 2 \mathrm{H}), 8.08\left(\mathrm{dd}, 2 \mathrm{H}, J_{1}=4.0 \mathrm{~Hz}, J_{2}=4.0 \mathrm{~Hz}\right), 7.93(\mathrm{dd}, 1 \mathrm{H}$, $\left.J_{1}=4.0 \mathrm{~Hz}, J_{2}=4.0 \mathrm{~Hz}\right), 7.88\left(\mathrm{dd}, 1 \mathrm{H}, J_{1}=4.0 \mathrm{~Hz}, J_{2}=4.0 \mathrm{~Hz}\right), 7.43\left(\mathrm{dd}, 2 \mathrm{H}, J_{1}=4.0 \mathrm{~Hz}\right.$, $\left.J_{2}=4.0 \mathrm{~Hz}\right)$.

\subsubsection{Synthesis of Complexes 1 and $\mathbf{2}$}

The pni $(0.140 \mathrm{~g}, 0.4 \mathrm{mmol})$ was mixed with an ethylene glycol $(10 \mathrm{~mL})$ solution of the precursor ruthenium complexes $(0.4 \mathrm{mmol})$. After refluxing under argon for $8 \mathrm{~h}$, the addition of $\mathrm{KPF}_{6}$ yielded a dark red precipitate. The final products were obtained using an aluminium oxide column with $20 \%$ toluene in acetonitrile.

[Ru(bpy $\left.)_{2}(\mathrm{pni})\right]\left(\mathrm{PF}_{6}\right)_{2}$ (1), Yield: 40.1\%. (Found: C, 49.04; H, 2.90; N, 10.72\%. Calcd for $\left.\mathrm{C}_{43} \mathrm{H}_{30} \mathrm{~N}_{8} \mathrm{~F}_{12} \mathrm{P}_{2} \mathrm{Ru}: \mathrm{C}, 49.20 ; \mathrm{H}, 2.88 ; \mathrm{N}, 10.67 \%\right)$. ES-MS $\left(\mathrm{CH}_{3} \mathrm{CN}\right): \mathrm{m} / \mathrm{z}=904.6$ ([M-PF6] $]^{+}$), $379.8\left(\left[\mathrm{M}-2 \mathrm{PF}_{6}\right]^{2+}\right) .{ }^{1} \mathrm{H}$ NMR $\left(400 \mathrm{MHz}, \mathrm{ppm}, \mathrm{DMSO}-\mathrm{d}^{6}\right): 13.47(\mathrm{~s}, 1 \mathrm{H}), 10.11(\mathrm{~d}, 1 \mathrm{H}$, $J=8.0 \mathrm{~Hz}), 9.10(\mathrm{~s}, 1 \mathrm{H}), 8.87(\mathrm{~d}, 5 \mathrm{H}, J=8.0 \mathrm{~Hz}), 8.41(\mathrm{~s}, 1 \mathrm{H}), 8.24(\mathrm{~m}, 4 \mathrm{H}), 8.18(\mathrm{~s}, 1 \mathrm{H})$, $8.12(\mathrm{~d}, 4 \mathrm{H}, J=8.0 \mathrm{~Hz}), 8.04\left(\mathrm{dd}, 1 \mathrm{H}, J_{1}=8.0 \mathrm{~Hz}, J_{2}=8.0 \mathrm{~Hz}\right), 7.97\left(\mathrm{dd}, 1 \mathrm{H}, J_{1}=8.0 \mathrm{~Hz}\right.$, $\left.J_{2}=8.0 \mathrm{~Hz}\right), 7.86(\mathrm{~d}, 2 \mathrm{H}, J=4.0 \mathrm{~Hz}), 7.67\left(\mathrm{dd}, 2 \mathrm{H}, J_{1}=8.0 \mathrm{~Hz}, J_{2}=8.0 \mathrm{~Hz}\right), 7.60(\mathrm{t}, 2 \mathrm{H}$, 
$\left.J_{1}=4.0 \mathrm{~Hz}, J_{2}=4.0 \mathrm{~Hz}\right), 7.47\left(\mathrm{t}, 2 \mathrm{H}, J_{1}=8.0 \mathrm{~Hz}, J_{2}=8.0 \mathrm{~Hz}\right), 7.38\left(\mathrm{t}, 2 \mathrm{H}, J_{1}=8.0 \mathrm{~Hz}\right.$, $\left.J_{2}=8.0 \mathrm{~Hz}\right) .{ }^{13} \mathrm{C}$ NMR $\left(101 \mathrm{MHz}, \mathrm{ppm}, \mathrm{DMSO}-\mathrm{d}^{6}\right): 157.26,157.03,153.83,153.40,153.10$, $151.96,148.02,147.85,144.60,138.49,138.37,137.68,136.95,135.33,131.29,130.41,129.87$, $129.23,128.74,128.36,128.27,128.01,127.58,127.17,124.93,123.92,116.72,107.63$.

$\left[\mathrm{Ru}(\mathrm{phen})_{2}(\mathrm{pni})\right]\left(\mathrm{PF}_{6}\right)_{2}$ (2), Yield: 51.3\%. Anal (\%): (Found: $\mathrm{C}, 51.37 ; \mathrm{H}, 2.79 ; \mathrm{N}, 10.27 \%$, Calc for $\mathrm{C}_{47} \mathrm{H}_{30} \mathrm{~N}_{8} \mathrm{~F}_{12} \mathrm{P}_{2} \mathrm{Ru}$ : C, 51.42; $\mathrm{H}, 2.75 ; \mathrm{N}, 10.21 \%$ ). ES-MS $\left(\mathrm{CH}_{3} \mathrm{CN}\right): \mathrm{m} / \mathrm{z}=952.7$ ([MPF6 $\left.]^{+}\right), 403.8\left(\left[\mathrm{M}-2 \mathrm{PF}_{6}\right]^{2+}\right) .{ }^{1} \mathrm{H}-\mathrm{NMR}\left(400 \mathrm{MHz}, \mathrm{ppm}, \mathrm{DMSO}-\mathrm{d}^{6}\right): 13.48(\mathrm{~s}, 1 \mathrm{H}), 10.11(\mathrm{~d}$, $1 \mathrm{H}, J=8.0 \mathrm{~Hz}), 9.07(\mathrm{~s}, 1 \mathrm{H}), 8.85(\mathrm{~d}, 1 \mathrm{H}, J=4.0 \mathrm{~Hz}), 8.80(\mathrm{~d}, 4 \mathrm{H}, J=8.0 \mathrm{~Hz}), 8.41(\mathrm{~s}, 4 \mathrm{H})$, $8.21(\mathrm{~m}, 4 \mathrm{H}), 8.11(\mathrm{~m}, 4 \mathrm{H}), 7.93\left(\mathrm{dd}, 1 \mathrm{H}, J_{1}=4.0 \mathrm{~Hz}, J_{2}=4.0 \mathrm{~Hz}\right), 7.81(\mathrm{~m}, 5 \mathrm{H}), 7.45(\mathrm{t}, 2 \mathrm{H}$, $\left.J_{1}=8.0 \mathrm{~Hz}, J_{2}=8.0 \mathrm{~Hz}\right), 7.25\left(\mathrm{t}, 1 \mathrm{H}, J_{1}=8.0 \mathrm{~Hz}, J_{2}=8.0 \mathrm{~Hz}\right), 7.16\left(\mathrm{~d}, 1 \mathrm{H}, J_{1}=8.0 \mathrm{~Hz}\right.$, $\left.J_{2}=8.0 \mathrm{~Hz}\right) .{ }^{13} \mathrm{C}-\mathrm{NMR}\left(101 \mathrm{MHz}, \mathrm{ppm}, \mathrm{DMSO}-\mathrm{d}^{6}\right): 154.36,153.66,153.47,153.23,148.44$, $148.29,147.69,147.63,144.64,137.82,137.62,137.37,136.92,135.35,131.30,130.98,130.95$, $130.40,129.84,129.37,129.21,128.75,128.68,128.54,128.01,127.57,127.46,127.06,126.82$, $125.79,124.90,123.91,116.72,107.63$.

\section{Conclusions}

In this work, two ruthenium complexes were prepared. The ligand pni was obtained by introducing a naphthoimidazole unit at the 5-position of the phen. These complexes exhibited high DNA affinities through their DNA intercalative mode. Photoinduced DNA cleavages demonstrated that they can cleave DNA effectively. Mechanism experimental results indicated that they can produce singlet oxygen under irradiation and display high ${ }^{1} \mathrm{O}_{2}$ quantum yields. Photocytotoxicity results showed that the two complexes displayed low dark cytotoxicity, high phototoxicity, and large PI values. They display great potential for application as photocytotoxic agents through the modification of the main ligand.

Supplementary Materials: The following are available online, Figure S1: ${ }^{1} \mathrm{H}-\mathrm{NMR}$ in aromatic region of the ligand pni(top), complex 1 and 2 in $\left(\mathrm{CD}_{3}\right)_{2} \mathrm{SO}(400 \mathrm{MHz})$; Figure S2: ${ }^{13} \mathrm{C}-\mathrm{NMR}$ in aromatic region of complex $\mathbf{1}$ and $\mathbf{2}$ (bottom) in $\left(\mathrm{CD}_{3}\right)_{2} \mathrm{SO}(100 \mathrm{MHz})$; Figures S3 and Figure S4: Cell viabilities of HeLa and A375 cells pretreated with various concentrations complexes $\mathbf{1}$ and $\mathbf{2}$ for $12 \mathrm{~h}$ and irradiated at $450 \mathrm{~nm}$, for $10 \mathrm{~min}\left(6 \mathrm{~mW} / \mathrm{cm}^{2}\right)$. Equation (S1) and (S2): The ${ }^{1} \mathrm{O}_{2}$ generation quantum yield $(\Phi \Delta)$ equations.

Author Contributions: X.H. prepared the manuscript and completed most of the experiments. N.Y.L., Y.-Q.D., S.W., T.L. performed the DNA photocleavage experiments. X.-W.L. supervised the experiment and revised the manuscript. All authors have read and agreed to the published version of the manuscript.

Funding: This research was funded by the Research Foundation of the Education Bureau of Hunan Province (16A145).

Institutional Review Board Statement: Not applicable.

Informed Consent Statement: Not applicable.

Data Availability Statement: Not applicable.

Acknowledgments: Authors are grateful to the Education Bureau of Hunan Province for funding the work.

Conflicts of Interest: The authors declare no conflict of interest.

Sample Availability: Samples of the compounds $\mathbf{1}$ and $\mathbf{2}$ are available from the authors.

\section{References}

1. Zeng, L.L.; Gupta, P.; Chen, Y.; Wang, E.; Ji, L.N.; Chao, H.; Chen, Z.S. The development of anticancer ruthenium (II) complexes: From single molecule compounds to nanomaterials. Chem. Soc. Rev. 2017, 46, 5771-5804. [CrossRef]

2. Furrer, J.; Süss-Fink, G. Thiolato-bridged dinuclear arene ruthenium complexes and their potential as anticancer drugs. Coord. Chem. Rev. 2016, 309, 36-50. [CrossRef]

3. Li, F.; Collins, J.G.; Keene, F.R. Ruthenium complexes as antimicrobial agents. Chem. Soc. Rev. 2015, 44, 2529-2542. [CrossRef] 
4. Shi, G.; Monro, S.; Hennigar, R.; Colpitts, J.; Fong, J.; Kasimova, K.; Yin, H.; DeCoste, R.; Spencer, C.; Chamberlain, L. Ru(II) dyads derived from $\alpha$-oligothiophenes: A new class of potent and versatile photosensitizers for PDT. Coord. Chem. Rev. 2015, 282, 127-138. [CrossRef]

5. Liu, H.K.; Sadler, P.J. Metal complexes as DNA intercalators. Acc. Chem. Res. 2011, 44, 349-359. [CrossRef] [PubMed]

6. Genereux, J.C.; Barton, J.K. Mechanisms for DNA charge transport. Chem. Rev. 2010, 110, 1642-1662. [CrossRef] [PubMed]

7. Keene, F.R.; Smith, J.A.; Collins, J.G. Metal complexes as structure-selective binding agents for nucleic acids. Coord. Chem. Rev. 2009, 253, 2021-2035. [CrossRef]

8. Dervan, P.B. Molecular recognition of DNA by small molecules. Bioorg. Med. Chem. 2001, 9, 2215-2235. [CrossRef]

9. Lippert, B. Cisplatin: Chemistry and Biochemistry of a Leading Anti-Cancer Drug; Wiley-VCH: Weinheim, Germany, 1999.

10. Reedijk, J. Improved understanding in platinium antitumour chemistry. Chem. Commun. 1996, 1996, 801-806. [CrossRef]

11. Guo, Z.J.; Sadler, P.J. Medicinal inorganic chemistry. Adv. Inorg. Chem. 2000, 49, 183-306.

12. Roberts, J.D.; Peroutka, J.; Farrell, N. Cellular pharmacology of polynuclear platinum anti-cancer agents. J. Inorg. Biochem. 1999, 77, 51-57. [CrossRef]

13. Martnez, R.; Chacn-Garca, L. The search of DNA-intercalators as. antitumoral drugs: What it worked and what did not work. Curr. Med. Chem. 2005, 12, 127-151. [CrossRef]

14. Wan, D.; Tang, B.; Wang, Y.J.; Guo, B.H.; Yin, H.; Yi, Q.Y.; Liu, Y.J. Synthesis and anticancer properties of ruthenium (II) complexes as potent apoptosis inducers through mitochondrial disruption. Eur. J. Med. Chem. 2017, 139, 180-190. [CrossRef] [PubMed]

15. Tang, B.; Shen, F.; Wan, D.; Guo, B.H.; Wang, Y.J.; Yi, Q.Y.; Liu, Y.J. DNA-binding; molecular docking studies and biological activity studies of ruthenium (II) polypyridyl complexes. RSC Adv. 2017, 405, 228-234. [CrossRef]

16. Wan, D.; Lai, S.H.; Zeng, C.C.; Zhang, C.; Tang, B.; Liu, Y.J. Ruthenium (II) polypyridyl complexes: Synthesis, characterization and anticancer activity studies on BEL-7402 cells. J. Inorg. Biochem. 2017, 173, 1-11. [CrossRef] [PubMed]

17. Clark, M.J.E. Ruthenium and Other Metal Complexes in Cancer Chemotherapy; Springer: Berlin/Heidelberg, Germany, 1989.

18. Fan, C.D.; Wu, Q.; Chen, T.F.; Zhang, Y.B.; Zheng, W.J.; Wang, Q.; Mei, W.J. Arene ruthenium (II) complexes induce S-phase arrest in MG-63 cells through stabilization of c-Myc G-quadruplex DNA. Med. Chem. Commun. 2014, 5, 597-602. [CrossRef]

19. Fernández, R.; Melchart, M.; Habtemariam, A.; Parsons, S.; Sadler, P.J. Use of Chelating Ligands to Tune the Reactive Site of Half-Sandwich Ruthenium (II)-Arene Anticancer Complexes. Chem. Eur. J. 2004, 10, 5173-5179. [CrossRef] [PubMed]

20. Levina, A.; Mitra, A.; Lay, P.A. Recent developments in ruthenium anticancer drugs. Metallomics 2009, 1, 458-470. [CrossRef]

21. Gill, M.R.; Thomas, J.A. Ruthenium (II) polypyridyl complexes and DNA-From structural probes to cellular imaging and therapeutics. Chem. Soc. Rev. 2012, 41, 3179-3192. [CrossRef]

22. Yao, J.L.; Gao, X.; Sun, W.L.; Fan, X.Z.; Shi, S.; Yao, T.M. A naked-eye on-off-on molecular "light switch" based on a reversible "conformational switch" of G-quadruplex DNA. Inorg. Chem. 2012, 51, 12591-12593. [CrossRef]

23. Baggaley, E.; Gill, M.R.; Green, N.H.; Turton, D.; Sazanovich, I.V.; Botchway, S.W.; Smythe, C.; Haycock, J.W.; Weinstein, J.A.; Thomas, J.A. Dinuclear Ruthenium(II) Complexes as Two-Photon, Time-Resolved Emission Microscopy Probes for Cellular DNA. Angew. Chem. Int. Ed. Engl. 2014, 53, 3367-3371. [CrossRef]

24. Gill, M.R.; Gracia-Lara, J.; Foster, S.J.; Smythe, C.; Battaglia, G.; Thomas, J.A. A ruthenium (II) polypyridyl complex for direct imaging of DNA structure in living cells. Nat. Chem. 2009, 1, 662-667. [CrossRef] [PubMed]

25. Hartshorn, R.M.; Barton, J.K. Novel dipyridophenazine complexes of ruthenium (II): Exploring luminescent reporters of DNA. J. Am. Chem. Soc. 1992, 114, 5919-5925. [CrossRef]

26. Ghosh, G.; Colon, K.L.; Fuller, A.; Sainuddin, T.; Bradner, E.; McCain, J.; Monro, S.M.A.; Yin, H.M.; Hetu, M.W.; Cameron, C.G.; et al. Cyclometalated Ruthenium(II) Complexes Derived from $\alpha$-Oligothiophenes as Highly Selective Cytotoxic or Photocytotoxic Agents. Inorg. Chem. 2018, 57, 7694-7712.

27. Silva-Caldeira, P.P.; Oliveira Junior, A.C.A.; Pereira-Maia, E.C. Photocytotoxic Activity of Ruthenium(II) Complexes with Phenanthroline-Hydrazone Ligands. Molecules 2021, 26, 2084-2095. [CrossRef]

28. Rizvi, I.; Anbil, S.; Alagic, N.; Celli, J.P.; Zheng, L.Z.; Palanisami, A.; Glidden, M.D.; Pogue, B.W.; Hasan, T. PDT Dose Parameters Impact Tumoricidal Durability and Cell Death Pathways in a 3D Ovarian Cancer Model. Photochem. Photobiol. 2013, 89, 942-952. [CrossRef] [PubMed]

29. Chen, Y.; Guan, R.; Zhang, C.; Huang, J.; Ji, L.N.; Chao, H. Two-photon luminescent metal complexes for bioimaging and cancer phototherapy. Coord. Chem. Rev. 2016, 310, 16-40. [CrossRef]

30. Yu, H.J.; Liu, J.P.; Hao, Z.F.; He, J.; Sun, M.; Hu, S.; Yu, L.; Chao, H. Synthesis, characterization and biological evaluation of ruthenium(II) complexes $[\mathrm{Ru}(\mathrm{dtzp})(\mathrm{dppz}) \mathrm{Cl}]^{+}$and $[\mathrm{Ru}(\mathrm{dtzp})(\mathrm{dppz}) \mathrm{CH} 3 \mathrm{CN}] 2+$ for photodynamic therapy. Dyes Pigment. 2017, 136, 416-426. [CrossRef]

31. Zhang, J.X.; Zhou, J.W.; Chan, C.F.; Lau, T.C.K.; Kwong, D.W.J.; Tam, H.L.; Mak, N.K.; Wong, K.L.; Wong, W.K. Comparative Studies of the Cellular Uptake, Subcellular Localization, and Cytotoxic and Phototoxic Antitumor Properties of Ruthenium(II)-Porphyrin Conjugates with Different Linkers. Bioconjug. Chem. 2012, 23, 1623-1638. [CrossRef] [PubMed]

32. Zeng, L.L.; Kuang, S.; Li, G.Y.; Jin, C.Z.; Ji, L.N.; Ji, C.H. A GSH-activatable ruthenium(II)-azo photosensitizer for twophoton photodynamic therapy. Chem. Commun. 2017, 53, 1977-1980. [CrossRef]

33. Yip, A.M.H.; Lo, K.K.W. Luminescent rhenium(I), ruthenium(II), and iridium(III) polypyridine complexes containing a poly(ethylene glycol) pendant or bioorthogonal reaction group as biological probes and photocytotoxic agents. Coord. Chem. Rev. 2018, 361, 138-163. [CrossRef] 
34. Huang, H.Y.; Zhang, P.Y.; Yu, B.L.; Jin, C.Z.; Ji, L.N.; Chao, H. Synthesis, characterization and biological evaluation of mixed-ligand ruthenium(ii) complexes for photodynamic therapy. Dalton Trans. 2015, 44, 17335-17345. [CrossRef] [PubMed]

35. Huang, H.Y.; Yu, B.L.; Zhang, P.Y.; Huang, J.J.; Chen, Y.; Ji, L.N.; Chao, H. Chiral Highly Charged Ruthenium(II) Polypyridyl Complexes as Lysosome-Localized Photosensitizers for Two-Photon Photodynamic Therapy. Angew. Chem. Int. Ed. 2015, 54, 14049-14052. [CrossRef] [PubMed]

36. Karges, J.; Kuang, S.; Maschietto, F.; Blacque, O.; Ciofini, I.; Chao, H.; Gasser, G. Rationally designed ruthenium complexes for 1-and 2-photon photodynamic therapy. Nat. Comm. 2020, 11, 3262. [CrossRef] [PubMed]

37. Ellahioui, Y.; Patra, M.; Mari, C.; Kaabi, R.; Karges, J.; Gasser, G.; Gómez-Ruiz, S. Mesoporous silica nanoparticles functionalised with a photoactive ruthenium(ii) complex: Exploring the formulation of a metal-based photodynamic therapy photosensitiser. Dalton Trans. 2019, 48, 5940-5951. [CrossRef] [PubMed]

38. Conti, L.; Bencini, A.; Ferrante, C.; Gellini, C.; Paoli, P. Highly charged ruthenium (II) polypyridyl complexes as effective photosensitizer in photodynamic therapy. Chem. Eur. J. 2019, 25, 10606-10615. [CrossRef] [PubMed]

39. Liu, J.; Liao, X.; Xiong, K.; Kuang, S.; Jin, C.; Ji, L.N.; Chao, H. Boosting two-photon photodynamic therapy with mitochondriatargeting ruthenium-glucose conjugates. Chem. Commun. 2020, 56, 5839-5842. [CrossRef]

40. McGhee, J.D.; von Hippel, P.H. Theoretical aspects of DNA-protein interactions: Co-operative and non-cooperative binding of large ligands to a one-dimensional homogeneous lattice. J. Mol. Biol. 1974, 86, 469-489. [CrossRef]

41. Ambroise, A.; Maiya, B.G. Ruthenium (II) complexes of 6; 7-dicyanodipyridoquinoxaline: Synthesis; luminescence studies and DNA interaction. Inorg. Chem. 2000, 39, 4256-4263. [CrossRef]

42. Liu, J.G.; Ye, B.H.; Li, H.; Ji, L.N.; Li, R.H.; Zhou, J.Y. Synthesis; characterization and DNA-binding properties of novel dipyridophenazine complex of ruthenium (II):[Ru(IP) $\left.)_{2}(\mathrm{DPPZ})\right]^{2+}$. J. Inorg. Biochem. 1999, 73, 117-122. [CrossRef]

43. Ji, L.N.; Zou, X.H.; Liu, J.G. Shape-and enantioselective interaction of Ru (II)/Co (III) polypyridyl complexes with DNA. Coord. Chem. Rev. 2001, 216-217, 513-536. [CrossRef]

44. Cohen, G.; Eisenberg, H. Viscosity and sedimentation study of sonicated DNA-proflavine complexes. Biopolymers 1969, 8, 45-55. [CrossRef]

45. Satyanarayana, S.; Dabroniak, J.C.; Chaires, J.B. Neither. DELTA.-nor. LAMBDA.-tris (phenanthroline) ruthenium (II) binds to DNA by classical intercalation. Biochemistry 1992, 31, 9319-9324. [CrossRef] [PubMed]

46. Satyanarayana, S.; Dabroniak, J.C.; Chaires, J.B. Tris(phenanthroline) ruthenium (II) enantiomer interactions with DNA: Mode and specificity of binding. Biochemistry 1993, 32, 2573-2584. [CrossRef] [PubMed]

47. Burya, S.J.; Lutterman, D.A.; Turro, C. Absence of quenching by $\left[\mathrm{Fe}(\mathrm{CN})_{6}\right]^{4-}$ is not proof of DNA intercalation. Chem. Comm. 2011, 47, 1848-1850. [CrossRef] [PubMed]

48. Nilsson, F.R.; Merkel, P.B.; Kearns, D.R. Unambiguous evidence for the participation of singlet oxygen in photodynamic oxidation of amino acids. Photochem. Photobiol. 1972, 16, 117-124. [CrossRef] [PubMed]

49. Chen, X.; Gao, F.; Yang, W.Y.; Zhou, Z.X.; Lin, J.Q.; Ji, L.N. StructureActivity Relationship of Polypyridyl Ruthenium(II) Complexes as DNA Intercalators, DNA Photocleavage Reagents, and DNA Topoisomerase and RNA Polymerase Inhibitors. Chem. Biodivers. 2013, 10, 367-384. [CrossRef]

50. Tan, L.F.; Chao, H. DNA-binding and photocleavage studies of mixed polypyridyl ruthenium(II) complexes with calf thymus DNA. Inorg. Chim. Acta 2007, 360, 2016-2022. [CrossRef]

51. Abdel-Shafi, A.A.; Beer, P.D.; Mortimer, R.J.; Wilkinson, F. Photosensitized Generation of Singlet Oxygen from Vinyl Linked Benzo-Crown-Ether-Bipyridyl Ruthenium(II) Complexes. J. Phys. Chem. A 2000, 104, 192-202. [CrossRef]

52. Albani, B.A.; Peña, B.; Leed, N.A.; de Paula, N.A.B.G.; Pavani, C.; Baptista, M.S.; Dunbar, K.R.; Turro, C. Marked Improvement in Photoinduced Cell Death bya New Tris-Heteroleptic Complex with Dual Action: Singlet Oxygen Sensitization and Ligand Dissociation. J. Am. Chem. Soc. 2014, 136, 17095-17101. [CrossRef]

53. Yu, H.J.; Huang, S.M.; Li, L.Y.; Jia, H.N.; Chao, H.; Mao, Z.W.; Liu, J.Z.; Ji, L.N. Synthesis, DNA-binding and photocleavage studies of ruthenium complexes $\left[\mathrm{Ru}(\mathrm{bpy})_{2}(\text { mitatp) }]^{2+}\right.$ and $\left[\mathrm{Ru}(\mathrm{bpy})_{2}(\text { nitatp) }]^{2+}\right.$. J. Inorg. Biochem. 2009, 103, 881-890. [CrossRef] [PubMed]

54. Bolger, J.; Gourdon, A.; Ishow, E.; Launay, J.P. Mononuclear and Binuclear Tetrapyrido [3;2-a:2 $\left.; 3^{\prime}-\mathrm{c}: 3^{\prime \prime} ; 2^{\prime \prime}-\mathrm{h}: 2^{\prime \prime \prime} ; 3^{\prime \prime \prime}-\mathrm{j}\right]$ phenazine (tpphz) Ruthenium and Osmium Complexes. Inorg. Chem. 1996, 35, 2937-2944. [CrossRef]

55. Ishow, E.; Gourdon, A.; Launay, J.P. Observation of supramolecular $\pi-\pi$ dimerization of a dinuclear ruthenium complex by ${ }^{1} \mathrm{H}$ NMR and ESMS. Chem. Commun. 1998, 17, 1909-1910. [CrossRef]

56. Zaid, A.; Sun, J.S.; Nguyen, C.H.; Bisagni, E.; Garestier, T.; Grierson, D.S.; Zain, R. Triple-Helix Directed Cleavage of DoubleStranded DNA by Benzoquinoquinoxaline-1; 10-phenanthroline Conjugates. ChemBioChem 2004, 5, 1550-1557. [CrossRef] 